UDC 006.013

МРНТИ 84.01.11

DOI: https://doi.org/10.37788/2021-2/72-80

\author{
A.P. Kucher ${ }^{1}$, A.V. Chernovol ${ }^{1}$, M.V. Temerbayeva ${ }^{1}$ \\ ${ }^{1}$ Innovativee University of Eurasia, Republic of Kazakhstan \\ (e-mail: a-sandra-k@mail.ru)
}

\title{
The sphere of physical protection of objects in the new conditions of public administration in Kazakhstan
}

\begin{abstract}
Annotation
The main problem: The article analyzes the situation that has developed in the market for the provision of services in the field of physical protection of objects vulnerable to terrorism, as objects of special importance for ensuring national security. The main problems hindering the development of the industry are: the lack of a comprehensive regulatory framework that establishes requirements for all aspects of the use of physical protection systems at all stages of the life cycle, from design to decommissioning, taking into account risk assessment; the formal nature of control procedures, which does not take into account all aspects of interdisciplinary interaction; the low involvement of qualified specialists in the process of developing approaches that ensure effective regulation of the industry.

Purpose: The main goal in the current conditions is to develop a model of interaction between state bodies and the professional community, which will effectively regulate the relations between the subjects of activity in the field of protecting objects vulnerable to terrorism (here in after OVT).

Methods: The authors of the article analyzed the regulatory legal framework. The conditions that impede the development of the industry have been identified. The message of the President of Kazakhstan in terms of directions for the development of the public administration system was also studied. The modeling of the processes and connections between the subjects of activity in the field of protection of the OVT has been carried out.

Results and their significance: The main reason for the insufficient level of protection was revealed, which boils down to the absence of criteria for assessing protection systems in terms of quality indicators. This is facilitated by the insufficient competence of technical specialists developing requirements for systems and ignoring the application of standards, as well as insufficient involvement of the professional community in control over the activities of market entities. The authors of the article proposed a model of a management system for the protection of OVT, which will improve the quality of processes and ensure the result due to the additional involvement of the professional community and the development of regulatory documents. In addition, the model corresponds to the course of development of the public administration system, which is set by the country's leadership. A number of proposals have been formulated for the implementation of a new model of the OVT protection management system. The model describes the interaction of government agencies and the professional community.
\end{abstract}

Key words: safeness, video surveillance, system, security, protection, alarm.

\section{Introduction}

At all times, the issue of personal safety, as well as the safety of property has been relevant. Today, a significant role is assigned to technical means of safety and physical protection. It is already difficult to imagine our life without video surveillance, burglar alarms, intercoms or turnstiles.

The modern concept of a physical protection system is quite broadly interpreted and can include (but not limited to) systems and means:

- automatic fire extinguishing and automatic fire alarm, warning and evacuation control in case of fire;

- security and alarm;

- transmission of notifications;

- security television (video monitoring);

- control and management of access;

- engineering and technical fortification and other elements directly or indirectly involved in the process of ensuring the protection of objects (service cynology, operational-search activities, profiling, etc.).

Until the 2000s, in Kazakhstan, the protection of objects of all forms of ownership was carried out by a special service in the system of the Ministry of Internal Affairs - non-departmental security. Comprehensive regulation was provided not only by a significant number of instructions, recommendations, orders, but also by discussion and explanation of models for solving specific problems on the pages of a specialized periodical. The professional community and the regulation of its activities were, by and large, a single structure in the system of the Ministry of Internal Affairs. One can argue about justification, but the system was quite effective, and the existing shortcomings were compensated for by broad powers, lack of competition and the scale of client coverage. 
Since the beginning of the 2000s, a course was taken to transfer the functions of protecting objects into the hands of private security organizations, whose capabilities were significantly inferior to state bodies. From about the same period, the range of technical means used in the protection of objects has expanded. Today in Kazakhstan the sphere of security activities is regulated by a special Law [1]. Security activity is understood as the implementation by legal entities of activities to provide services to protect the life, health and property of individuals, as well as property of legal entities from unlawful encroachments (security services). To carry out security activities, an appropriate license is required. You also need a license to design a fire and security alarm. A notification procedure is provided for the installation, commissioning and maintenance of security alarm systems. In other cases, there are no special requirements or restrictions for entrepreneurs' access to the market of physical protection systems, which determines the presence of risks associated with equipment and personnel.

Separately, among the objects to be protected, objects that are vulnerable to terrorism are considered (further OVT). Their list [2] is approved by the relevant decree of the Government of the Republic of Kazakhstan.

\section{Materials and methods}

To protect the OVT, legal, organizational, engineering, special, security and other measures are taken to increase the level of anti-terrorist security of these facilities and the readiness of state bodies and legal entities to eliminate and (or) minimize the consequences of acts of terrorism [3].

The regulation of OVT protection activities includes:

- licensing of subjects of security activity [4], which performs the function of admission to the OVT security market;

- regulation of the anti-terrorist protection system OVT [5];

- regulation of engineering and technical fortification of objects subject to state protection [6].

Today, a complex of organizational and technical measures to counter infringements on property rights, health and life, as well as the architecture of an enterprise * is usually called a physical protection system (further PPS).

The most important role in the protection of objects is played by the person and the management system (management) of the enterprise. The existing approach in PPS OVT management cannot be recognized as effective due to the absence of a process description of links in a set of activities, an insufficient degree of elaboration of requirements and formalization of the OVT protection process. A number of decisions are made by the heads of facilities and departments on the basis of the results of commission surveys [6, Section 1, clause 1, clause 4] (or without them) in the absence of management and risk assessment, any indications of quality criteria or methodologies for assessing effectiveness such protection. As a result, the quality level of the OVT protection system may suffer.

International best practice takes into account many factors in constructing the PPS. Threat analysis and risk assessment are carried out, a model of an intruder is developed, complex technical and organizational systems are designed, and appropriate personnel are selected to counteract. Without the use of a developed system of regulatory, technical and methodological documents, even an experienced person is not always able to solve the issue of effective protection. Different countries use different approaches, but regulation of the security sector always remains under government control.

In Kazakhstan today, a comprehensive regulatory framework has not been formed that establishes requirements for all aspects of the application of PPS (including quality indicators), and the adopted documents can be performed selectively or not systematically. The current situation is due to a number of factors:

- frequent reorganizations of executive bodies and a change in areas of responsibility between them;

- lack of qualified technical specialists in government bodies;

- a low level of regulation in the areas lying at the junctions of various areas of science and technology, areas of responsibility of various departments;

- lack of effective collaboration with the professional community.

In conditions when most of the security activities and the entire sphere of related services are transferred to a competitive environment, the state is obliged to ensure compliance with the principles of healthy competition. Competition should be based on legality, competition, honesty, and respect for consumer rights. Only in this case does it perform the most important functions of a market economy:

- stimulates scientific and technological progress;

- increases productivity and labor efficiency;

- promotes «natural selection» of enterprises;

- regulates pricing by balancing supply and demand.

However, in order to ensure healthy competition, it is fundamentally important to exclude any actions aimed at the emergence of undue advantages of some market participants. To obtain such an advantage, an unscrupulous entrepreneur may not be justified to reduce some qualitative indicators that are not always possible to identify without the involvement of an expert.

For example:

- The cable can be produced in accordance with GOST, ST RK or another standard and differ significantly in quality; 
- Devices and equipment of identical purpose may have different functionality and different indicators (warranty period, warranty service conditions, maintainability, service life, compatibility with other technical means, etc.)

- The software may differ in terms of hardware requirements, licensing terms, compliance with information security requirements, etc.);

- The quality characteristics of technical systems assembled even from the same elements can vary significantly due to the levels of competence of designers, installers and adjusters.

Thus, in addition to price, the main factor of competition is a complex quality indicator. In the absence of established quality indicators and assessment methods, price becomes the only criterion that determines the winner in the competition. And the desire to reduce prices, firstly, leads to equipping objects with systems with low consumer characteristics (since it is cheap), secondly, it does not provide reliable protection of objects (since few people dive into the details of the conditions of use), and thirdly, it leads to the degradation of the professional environment (why develop if they will buy the cheapest one anyway).

Naturally, the professional level is also gradually dropping to an unacceptably low level; the security guard profession has become one of the lowest qualified and least paid. Technicians striving for development are forced to change their field of activity or even leave the country for professional implementation. This state of affairs is generally recognized as requiring serious intervention to change regulatory approaches.

\section{Results}

Since 2021, amendments have been made to the Law [7] in terms of increasing the requirements for security activities at facilities vulnerable to terrorism (OVT). At the same time, no significant measures to improve the quality of the safety assurance process have been proposed in parallel. In fact, the list of formal requirements for the training program has been expanded extensively. Such measures are not capable of providing quality transformations in the industry.

It is important to understand that ensuring safety and security is a matter of building a harmonious and holistic system (Figure 1), consisting of three key elements:

- personnel;

- technics;

- procedures.

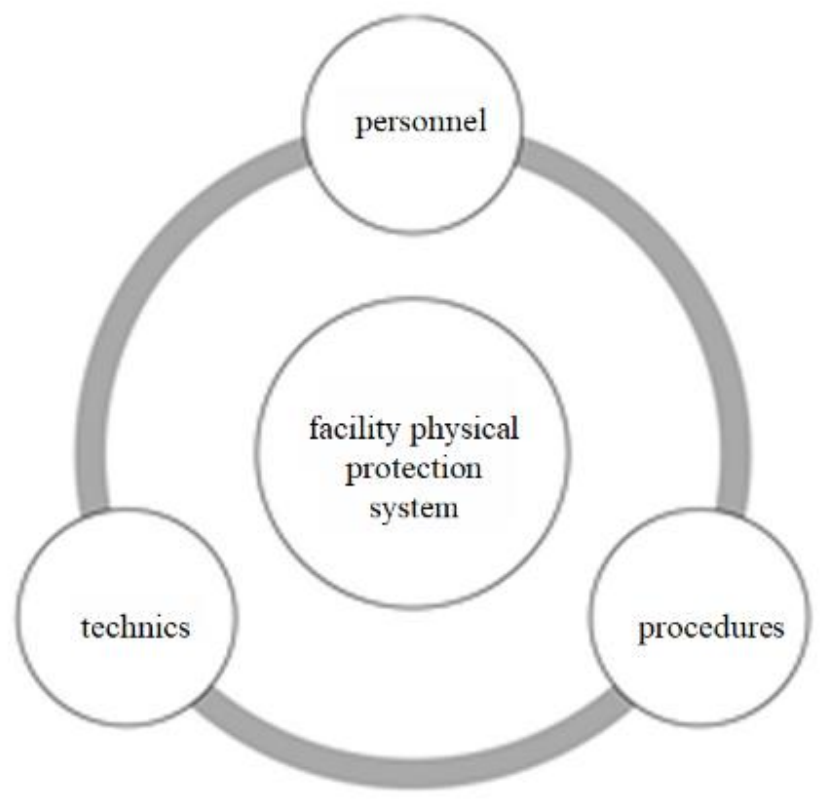

Figure 1 - The structure of the physical protection system of the facility

Personnel are the main element of the system. It is on the staff that a specific solution should be closed. The issue of personnel training should be resolved on the basis of competencies, which are determined based on the role of a specialist in the system, the nature of the functions performed and the object of protection (protection). However, within the framework of the current legislation, the requirements for the personnel of security organizations are limited by the need to complete a standard training program and pass the exam in a specialized training center. Naturally, such training does not always provide a sufficient level of competence to carry out activities at a specific facility. The question of checking such compliance remains with the head of the subject of protection and, as a rule, does not find a proper response. There is no generally accepted model for verifying the suitability of personnel for a wide range of tasks. For example, the degree of mastery of techniques for handling technical means is formally controlled and limited to the basic functionality. And the ability to 
effectively handle special technical means often determines the result of the process of protection and protection (especially in an emergency response).

Technology expands the capabilities of personnel and is often able to reduce the need or completely replace certain categories of employees within the framework of automated operation. The expediency of choosing one or another option for building a system of physical protection of an object is determined taking into account the availability of the necessary resources (human and material). Today, Kazakhstan has the most developed regulatory documentation in the field of fire safety. It so happened that this direction developed in isolation and was continuously monitored by a special state fire service. For 2021, the industry has technical regulations and dozens of national and interstate standards. Other elements of the systems of physical protection of objects are practically not covered by the regulation. Only a few voluntary standards have been adopted that cover only small segments of the technical field and do not provide sufficient regulation to reduce risks to acceptable levels.

The procedures accompanying the activities of personnel and the use of technical means should be properly documented. Procedures should be understood as the whole set of processes, elements and connections of the system, reflected in the relevant documentation (standards, requirements, regulations, instructions, procedures, rules, structure, plans, schemes, control programs, document forms, etc.) and aimed at ensuring effective interactions within the system and with external parties. In international practice, project management is widely used, based on appropriate methods, tools, techniques and competencies. In the Russian Federation, for example, GOST R ISO 21500-2014 Project Management Guidelines are used. There is no such standard in Kazakhstan today. Only if the records and documents are correctly drawn up and kept up-to-date can one count on the effective functioning of the entire system throughout the entire life cycle.

The professional community and consumers have long needed a new approach. For effective counteraction to anthropogenic threats, a leading factor in standards and methods is extremely important. It also means that the established norms must meet the state of the art in science and technology. With the development of international business, transnational corporations, leadership in innovation has moved from state to private structures. The development of modern technologies is moving at such a pace that in order to maintain competencies, it is necessary to constantly be in the learning process. It is impossible to ensure full-fledged effective management and control at all stages by the forces of state bodies without the involvement of private structures. Instead of a set of formal requirements for the composition of technical equipment and personnel, it is necessary to implement a systematic approach based on threat analysis, risk assessment and the selection of countermeasures from a proven arsenal of means (organizational and technical).

Questions arise: how to ensure that PPS OVT meets the needs of the state and citizens; who and in what form will formalize and maintain the state of the system at the level of technology development and management science.

In the message of the President of the Republic of Kazakhstan dated September 1, 2020 «KAZAKHSTAN IN NEW REALITY: TIME FOR ACTION», the head of state pointed out the need to change approaches in state regulation.

In particular, the new state management model provides for the involvement of the private business sector and society as a full-fledged partner at all stages: planning, execution and evaluation. This initiative is designed to ensure the priority of the result over the process, which fully meets the interests of the professional community. The president's message indicates the need to revise the rule-making issues, since often the powers and scope for the activity of the executive branch are limited by the norms of legislation.

\section{Discussion}

The proposed model for regulating the sphere of physical protection OVT will allow conscientious and professional market participants to qualitatively improve the level of their services, to receive decent remuneration for their work. At the same time, the model contains a mechanism for influencing subjects who have made deviations from the approved methods, leading to a decrease in the level of protection.

The new approach provides for the construction of a competition policy based on legality, equal opportunities for entrepreneurs, while meeting the quality criteria for security and related activities.

First of all, when building a new OVT control system for physical protection systems, it is necessary to develop a concept. A variant of the diagram reflecting the composition and connections of the system elements is shown in Figure 2.

The development of the concept will serve the cause of the evolutionary development of the industry and, as a result, can become an example for other areas.

The concept assumes as goals:

- ensuring the protection of life, health, property of citizens and organizations;

- minimization of risks associated with the use of weapons, special means and special rights, subjects of security activities;

- development of the professional community and public control.

Concept objectives:

- improvement of organizational, methodological and scientific and technical support of activities;

- advanced training of personnel, technical level of methodological documents, tools and systems; 
- harmonization of the rules and procedures of the management system with the requirements and criteria of international standards;

- certification of personnel, regulatory documents, tools and systems;

- formation of a databank of certified objects, regulatory documents, tools and systems.

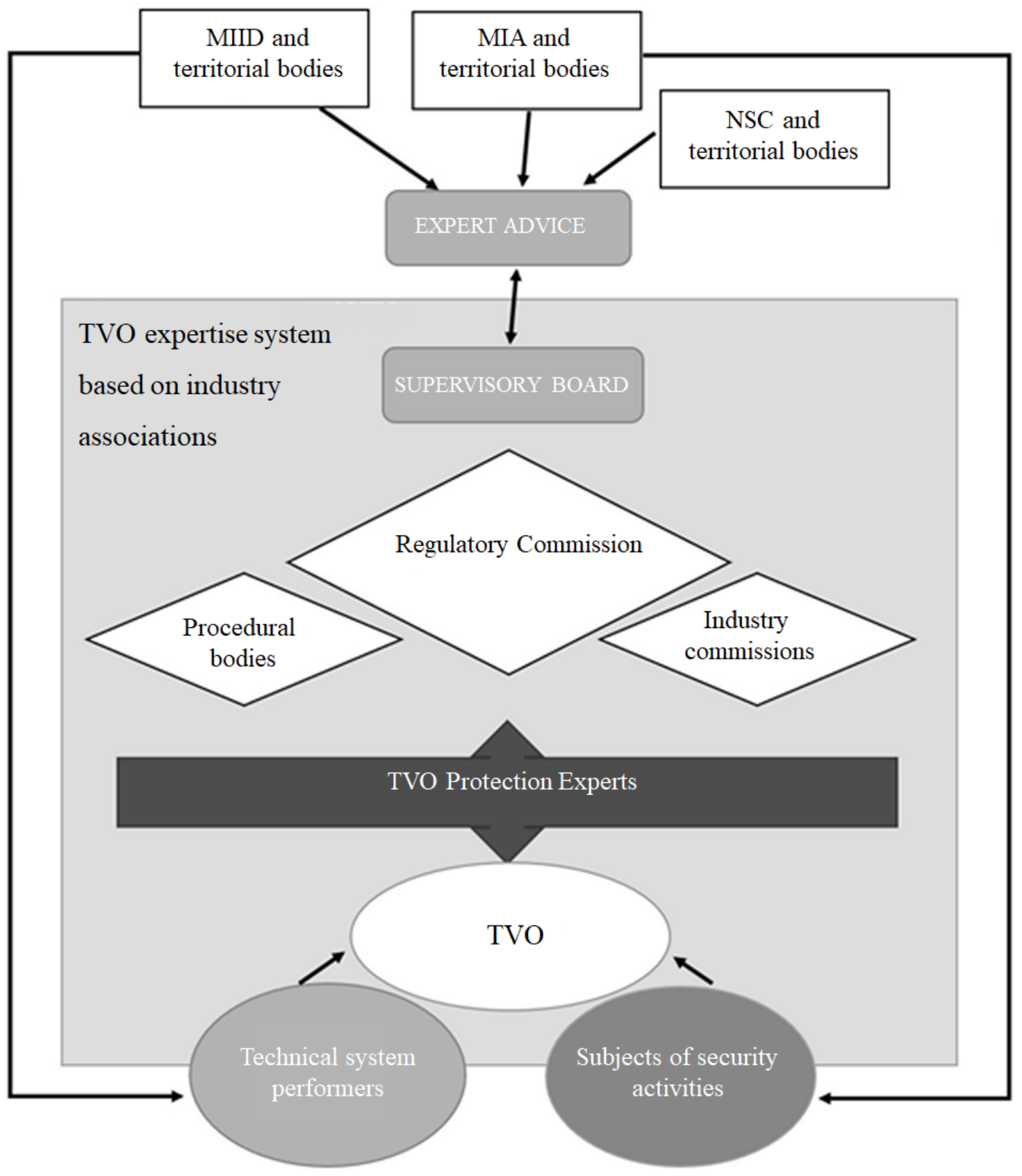

Figure 2 - Conceptual diagram of the OVT protection activity management system

According to the diagram presented in Figure 2, the Ministry of Industry and Infrastructure Development (MIID), through territorial bodies, carries out control and implementation functions in the field of architectural, urban planning and construction activities, including licensing the design of security and fire alarms. This allows qualified contractors to be admitted to develop PPS OVT solutions.

The national security committee (NSC) [8] coordinates activities in the field of countering terrorism in the Republic of Kazakhstan, thus directly interested in effective PPS OVT.

Through the licensing procedure by the Ministry of Internal Affairs (MIA) [9] in accordance with the Law [4, Appendix 1, p / n 86, Appendix 2, p / n 20], market entities are admitted to conduct activities associated with a high level of danger (security activity). The MIA also organizes and monitors the state of anti-terrorist security, coordinates, keeps records, storage and (or) destruction of anti-terrorist security passports for objects vulnerable to terrorist attitudes. 
Non-profit organizations (industry associations), in accordance with the Law [10], can conduct activities to achieve managerial, scientific goals in the field of OVT protection, to resolve disputes and conflicts arising in the field of activity, provide legal assistance, protect the rights and legitimate interests of their members.

Since 2015, Kazakhstan has adopted the Self-Regulation Law [11]. It provides for the creation of a mechanism to improve the quality of products and services on the market through the establishment of requirements for self-regulation entities and their activities above the requirements prescribed by the legislation of the Republic of Kazakhstan. To independently regulate the activities of its members, the association must develop and agree on a set of regulatory documents (organization standards) that provides comprehensive regulation of technical, personnel and procedural issues. By joining the association, a new member undertakes to comply with the approved standards and thereby achieve the compliance necessary for self-regulation.

There is an opinion that the concentration of powers in the hands of a non-profit organization can contribute to the emergence of non-market competition and even corruption. However, this risk is easily overcome, since the activities of associations of business entities in accordance with the Entrepreneurial Code [12] are based on:

1) equality of all business entities;

2) making decisions corresponding to the main directions of domestic and foreign policy of the state;

3 ) independence, which does not allow restrictions on the legally carried out activities of associations of business entities;

4) transparency of activities, accountability, responsibility to its members;

5) efficiency, consistency and efficiency in decision-making and their implementation (including the change of subjects of control).

Decisions regarding members of non-profit organizations are made collectively with the participation of experts representing different parties (government agencies and representatives of different business entities). In addition, the degree of risk is in any case lower than with regulation only by officials.

The law [11, Art. 3, p. 5] does not allow the creation of self-regulatory organizations in the field of national security, defense, public order, but in this case it is only about activities that create favorable conditions for state regulation. It is assumed that self-regulatory organizations do not carry out activities in these areas, just like a manufacturer of high-quality flour does not produce bread that is made from its raw materials. In this sense, the bread can be different, but if it is bad, it will definitely not be due to flour.

The Expert Council consists of authorized government officials (NSC, MIA, MIID) and accredited industry associations. The council conducts:

- analysis of the sufficiency of the current normative and normative technical documentation;

- development of recommendations on readiness for submission for approval of organizational, methodological, regulatory, technical, guidance documents for PPS OVT;

- development of recommendations for the development of PPS OVT.

The activities of the supervisory board are aimed at organizing and monitoring the activities of industry associations within the PPS OVT.

Procedural bodies plan and conduct activities to confirm that the activities of members of industry associations comply with the requirements of regulatory documents. Also, the procedural bodies are engaged in the consideration of complaints regarding decisions on the possibility of OVT certification, complaints from customers and other interested parties to the activities of the technical system performers and security entities.

The Regulatory Commission, together with leading organizations in the PPS field, develops the rules and procedures applicable to PPS OVT (for OVT certification, for expert certification, etc.).

The activities of the sectoral commissions are aimed at the development and control of specific requirements for PPS OVT of various industries (chemical, energy, transport, etc.), and also solve basic, professional tasks in areas corresponding to their competence.

OVT protection experts carry out activities to assess the compliance of the activities of members of industry associations with the requirements of regulatory documents in the implementation of contractual obligations with OVT.

Subjects of security activities carry out activities for the protection of OVTs provided for by legislation and agreements.

The entities executing the technical system ensure the equipping of the PPS OVT in accordance with the established procedures at all stages of the PPS life cycle.

\section{Conclusion}

The proposed approach assumes that the subjects of security activities and entrepreneurs of related fields will be offered recommendations in the form of step-by-step instructions with comments on each stage of the life cycle, links, descriptions of goals and expected results. Such a set of instructions should be linked into a single logical structure that ensures compliance with the requirements of regulatory legal acts and the achievement of the set goals. At the same time, the requirements for personnel (civil servants, civil servants) who will use such recommendations will be limited to simple implementation of instructions, and complex technical and organizational issues will fall on the performers (professional experts of non-profit organizations). 
The proposed approach is based on the definition of the list of threats by the authorized bodies, and in the case of anti-criminal measures, in addition, the model of the offender. Some of the threats will be relevant for almost any object (for example, the threat of a fire), and some threats are inherent in a narrow segment of objects.

For such special situations, an advisory body (sectoral commissions) should be envisaged, where decisions will be analyzed taking into account sectoral characteristics.

The main threats should be identified by the responsible persons (facility and / or agency) and identified for further risk assessment using suitable methods.

In risk assessment, the most popular method is the method of expert assessments. This method is the easiest to use, but it does not always provide correct and impartial assessments. The task of the professional community. Among other things, it is the selection of the optimal method for assessing each of the identified risks. Based on the results of the risk assessment, a decision should be made on the implementation of certain measures aimed at preventing or reducing damage from the implementation of a negative scenario. Estimates of possible damage can be obtained using the appropriate methodology and evaluated from the standpoint of an acceptable level of risk. When implementing the proposed approach, it is necessary to use international experience in standardization. Among the internationally accepted standards, an important role is played by risk management (eg ISO 31000: 2018 Risk management. Principles and guidelines) and security management (eg ISO 18788: 2015 Personal security operations management system. Requirements and guidance for use). In Kazakhstan, it is advisable to develop and adopt similar national standards that establish the relevant requirements.

In addition, within the framework of the current legislation, it would be extremely useful to develop and adopt a technical regulation «Requirements for the system of protection of objects vulnerable to terrorism» Within the framework of the approaches laid down in the technical regulations, the professional community could find effective ways to solve the entire complex of tasks that lie on the way to achieving the goal - effective protection of OVT.

It is possible to radically improve the state of affairs on the market only through joint efforts of state bodies and a close-knit professional community. As a result of concerted actions, you can get a mature market segment, extremely protected from the influence of destructive factors (incompetence, corruption, unfair competition, etc.).

In order to implement the above proposals, in 2020, Technical Committee for Standardization No. 115 «Security and Communications» was created on the basis of the Association of Legal Entities and Individual Entrepreneurs «Union of Security and Telecommunications Industry». This body intends to discuss the proposed approach to determine the vector of development of the security industry in Kazakhstan and to popularize it with a view to its widespread introduction into the business practice of Kazakhstan.

\section{THE LIST OF SOURCES}

1 Закон Республики Казахстан от 19 октября 2000 года № 85 «Об охранной деятельности» - Режим доступа: http://adilet.zan.kz/rus/docs/Z000000085_\#z1.

2 Постановление Правительства Республики Казахстан от 28 августа 2013 года № 876 «Об утверждении перечня объектов Республики Казахстан, уязвимых в террористическом отношении» - Режим доступа: http://adilet.zan.kz/rus/docs/P1300000876.

3 Закон Республики Казахстан от 13 июля 1999 года № 416 «О противодействии терроризму» - Режим доступа: http://adilet.zan.kz/rus/docs/Z990000416_.

4 Закон Республики Казахстан от 16 мая 2014 года № 202-V ЗРК «О разрешениях и уведомлениях»Режим доступа: http://adilet.zan.kz/rus/docs/Z1400000202.

5 Постановление Правительства Республики Казахстан от 3 апреля 2015 года №191 «Об утверждении требований к системе антитеррористической защиты объектов, уязвимых в террористическом отношении» - Режим доступа: http://adilet.zan.kz/rus/docs/P1500000191.

6 Постановление Правительства Республики Казахстан от 7 октября 2011 года № 1151 «Об утверждении требований по инженерно-технической укрепленности объектов, подлежащих государственной охране» - Режим доступа: http://adilet.zan.kz/rus/docs/P1100001151\#z44.

7 Закон Республики Казахстан от 2 января 2021 года № 405-VI ЗРК «О внесении изменений и дополнений в некоторые законодательные акты Республики Казахстан по вопросам охранной деятельности» - Режим доступа: http://adilet.zan.kz/rus/docs/Z2100000405.

8 Закон Республики Казахстан от 21 декабря 1995 года № 2710 «Об органах национальной безопасности Республики Казахстан» - Режим доступа: http://adilet.zan.kz/rus/docs/Z950002710_.

9 Закон Республики Казахстан от 23 апреля 2014 года № 199-V ЗРК «Об органах внутренних дел Республики Казахстан» - Режим доступа: http://adilet.zan.kz/rus/docs/Z1400000199.

10 Закон Республики Казахстан от 16 января 2001 года № 142 «О некоммерческих организациях»Режим доступа: http://adilet.zan.kz/rus/docs/Z010000142_.

11 Закон Республики Казахстан от 12 ноября 2015 года № 390-V ЗРК «О саморегулировании» - Режим доступа: http://adilet.zan.kz/rus/docs/Z1500000390. 
12 Кодекс Республики Казахстан от 29 октября 2015 года № 375-V ЗРК «Предпринимательский кодекс Республики Казахстан» - Режим доступа: http://adilet.zan.kz/rus/docs/K1500000375.

\title{
REFERENCE
}

1 Zakon Respubliki Kazahstan ot 19 oktyabrya 2000 goda № 85 «Ob ohrannoi deyatelnosti» [Law of the Republic of Kazakhstan dated October 19, 2000 No. 85 «On security activities»] (n.d.) Retrieved from http://adilet.zan.kz/rus/docs/Z000000085_\#z1 [in Russian].

2 Postanovlenie Pravitelstva Respubliki Kazahstan ot 28 avgusta 2013 goda № 876 «Ob utverzhdenii perechnya obektov Respubliki Kazahstan, uyazvimyh v terroristicheskom otnoshenii» [Resolution of the Government of the Republic of Kazakhstan dated August 28, 2013 No. 876 «On approval of the list of objects of the Republic of Kazakhstan vulnerable to terrorist attacks»] (n.d.) Retrieved from http://adilet.zan.kz/rus/docs/P1300000876 [in Russian].

3 Zakon Respubliki Kazahstan ot 13 iyulya 1999 goda № 416 «O protivodeistvii terrorizmu» [Law of the Republic of Kazakhstan dated July 13, 1999 No. 416 «On Countering Terrorism»] (n.d.) Retrieved from http://adilet.zan.kz/rus/docs/Z990000416_ [in Russian].

4 Zakon Respubliki Kazahstan ot 16 maya 2014 goda № 202-V ZRK «O razresheniyah i uvedomleniyah» [Law of the Republic of Kazakhstan dated May 16, 2014 № 202-V ZRK «On permissions and notifications»] (n.d.) Retrieved from http://adilet.zan.kz/rus/docs/Z1400000202 [in Russian].

5 Postanovlenie Pravitelstva Respubliki Kazahstan ot 3 aprelya 2015 goda №191 «Ob utverzhdenii trebovanii k sisteme antiterroristicheskoi zashchity obektov, uyazvimyh $\mathrm{v}$ terroristicheskom otnoshenii» [Decree of the Government of the Republic of Kazakhstan dated April 3, 2015 No. 191 «On approval of the requirements for the anti-terrorist protection system of objects vulnerable to terrorism»] (n.d.) Retrieved from http://adilet.zan.kz/rus/docs/P1500000191 [in Russian].

6 Postanovlenie Pravitelstva Respubliki Kazahstan ot 7 oktyabrya 2011 goda № 1151 «Ob utverzhdenii trebovanii po inzhenerno-tekhnicheskoi ukreplennosti obektov, podlezhashchih gosudarstvennoi ohrane» [Resolution of the Government of the Republic of Kazakhstan dated October 7, 2011 No. 1151 «On approval of requirements for engineering and technical strengthening of facilities subject to state protection»] (n.d.) Retrieved from http://adilet.zan.kz/rus/docs/P1100001151\#z44 [in Russian].

7 Zakon Respubliki Kazahstan ot 2 yanvarya 2021 goda № 405-VI ZRK «O vnesenii izmenenii i dopolnenii v nekotorye zakonodatelnye akty Respubliki Kazahstan po voprosam ohrannoi deyatelnosti» [Law of the Republic of Kazakhstan dated January 2, 2021 No. 405-VI ZRK «On Amendments and Additions to Certain Legislative Acts of the Republic of Kazakhstan on Security Activities»] (n.d.) Retrieved from http://adilet.zan.kz/rus/docs/Z2100000405 [in Russian].

8 Zakon Respubliki Kazahstan ot 21 dekabrya 1995 goda № 2710 «Ob organah natsionalnoi bezopasnosti Respubliki Kazahstan» [Law of the Republic of Kazakhstan dated December 21, 1995 No. 2710 «On the National Security Bodies of the Republic of Kazakhstan»] (n.d.) Retrieved from http://adilet.zan.kz/rus/docs/Z950002710_ [in Russian].

9 Zakon Respubliki Kazahstan ot 23 aprelya 2014 goda № 199-V ZRK «Ob organakh vnutrennikh del Respubliki Kazahstan» [Law of the Republic of Kazakhstan dated April 23, 2014 No. 199-V ZRK «On the Internal Affairs Bodies of the Republic of Kazakhstan»] (n.d.) Retrieved from http://adilet.zan.kz/rus/docs/Z1400000199 [in Russian].

10 Zakon Respubliki Kazahstan ot 16 yanvarya 2001 goda № 142 «O nekommercheskikh organizatsiyakh» [Law of the Republic of Kazakhstan dated January 16, 2001 No. 142 «On Noncommercial Organizations»] (n.d.) Retrieved from http://adilet.zan.kz/rus/docs/Z010000142_ [in Russian].

11 Zakon Respubliki Kazahstan ot 12 noyabrya 2015 goda № 390-V ZRK «O samoregulirovanii» [Law of the Republic of Kazakhstan dated November 12, 2015 No. 390-V ZRK «On self-regulation»] (n.d.) Retrieved from http://adilet.zan.kz/rus/docs/Z1500000390 [in Russian].

12 Kodeks Respubliki Kazahstan ot 29 oktyabrya 2015 goda № 375-V ZRK «Predprinimatelskii kodeks Respubliki Kazahstan» [Code of the Republic of Kazakhstan dated October 29, 2015 No. 375-V ZRK «Entrepreneurial Code of the Republic of Kazakhstan»](n.d.) Retrieved from http://adilet.zan.kz/rus/docs/K1500000375 [in Russian].

\author{
А.П. Кучер ${ }^{1 *}$, А.В. Черновол ${ }^{1}$, М.В. Темербаева ${ }^{1}$ \\ ${ }^{1}$ Инновациялық Еуразия университеті, Қазақстан Республикасы
}

\section{Қазақстанда мемлекеттік басқарудың жаңа жағдайындағы объектілерді физикалық қорғау саласы}

Мақалада ұлттық қауіпсіздікті қамтамасыз ету үшін ерекше маңызы бар объектілер ретінде терроризмге осал объектілерді физикалық қорғау саласындағы қызметтерді ұсыну нарығында қалыптасқан жағдай талданады. Саланың дамуына кедергі болатын негізгі проблемалар: өмірлік циклдің барлық кезеңдерінде, жобадан бастап қолданыстан шығаруға дейінгі, тәуекелді бағалауды ескере 
отырып, физикалық қорғаныс жүйелерін пайдаланудың барлық аспектілеріне қойылатын талаптарды белгілейтін кешенді нормативтік базаның болмауы; сектораралық өзара іс-қимылдың барлық аспектілері ескерілмейтін бақылау рәсімдерінің формальды сипаты; саланы тиімді реттеуді қамтамасыз ететін тәсілдерді әзірлеу процесіне білікті мамандардың аз тартылуы.

Техникалық құралдардың дамуы және күрделенуімен қауіпсіздікті тәжірибелік тұрғыдан шындықтың басты критерийі ретінде қарастырған жөн. Физикалық қорғау жүйелері, басқа күрделі жүйелер сияқты, іске асырылған кезде тиімді тәсілдерді қажет етеді.

Қазіргі жағдайдағы басты мақсат - террористік тұрғыдан осал объектілерді (бұдан әрі - TTOO) қорғау саласындағы қызмет субъектілері арасындағы қатынастарды тиімді реттейтін мемлекеттік органдар мен кәсіби қоғамдастықтың өзара әрекеттесу моделін құру.

Мақала авторлары нормативтік құқықтық базаны талдады. Саланың дамуына кедергі болатын жағдайлар анықталды. Мемлекеттік басқару жүйесін дамыту бағыттары бойынша Қазақстан Президентінің жолдауы да зерттелді. ТТОО қорғау саласындағы қызмет субъектілері арасындағы процестер мен байланыстарды модельдеу жүзеге асырылды.

Қорғаныс жүйесін сапа көрсеткіштері бойынша бағалау критерийлерінің болмауына байланысты жеткіліксіз қорғаныс деңгейінің басты себебі ашылды. Бұған жүйелерге қойылатын талаптарды әзірлейтін және стандарттарды қолдануды ескермейтін техникалық мамандардың жеткіліксіз құзыреттілігі, сондай-ақ нарық субъектілерінің қызметін бақылауға кәсіби қоғамдастықтың жеткіліксіз араласуы ықпал етеді. Мақала авторлары ТТОО қорғаудың басқару жүйесінің моделін ұсынады, бұл процестердің сапасын жақсартады және кәсіби қоғамдастықты қосымша тарту және нормативтік құжаттарды әзірлеу арқылы нәтижені қамтамасыз етеді. Сонымен қатар, модель ел басшылығы белгілейтін мемлекеттік басқару жүйесінің даму барысына сәйкес келеді. ТТОО қорғауды басқару жүйесінің жаңа моделін енгізу бойынша бірқатар ұсыныстар жасалды. Модель мемлекеттік органдар мен кәсіби қоғамдастықтың өзара әрекеттесуін сипаттайды.

Түйін сөздер: қауіпсіздік, бейнебақылау, жүйе, қауіпсіздік, қорғау, дабыл.

А.П. Кучер ${ }^{1 *}$, А.В. Черновол ${ }^{1}$, М.В. Темербаева ${ }^{1}$

${ }^{1}$ Инновационный Евразийский университет, Республика Казахстан

\section{Сфера физической защиты объектов в новых условиях государственного управления Казахстана}

В статье анализируется ситуация, сложившаяся на рынке оказания услуг в сфере физической защиты объектов, уязвимых в террористическом отношении, как объектов особого значения для обеспечения национальной безопасности. Основными проблемами, препятствующими развитию отрасли, являются: отсутствие всесторонней нормативной базы, устанавливающей требования ко всем аспектам применения систем физической защиты на всех этапах жизненного цикла, от проектирования до выведения из эксплуатации с учетом оценки рисков; формальный характер контрольных процедур, не учитывающий всех аспектов межотраслевого взаимодействия; низкое вовлечение квалифицированных специалистов в процесс разработки подходов, обеспечивающих эффективное регулирование отрасли.

Главной целью является выработка модели взаимодействия государственных органов и профессионального сообщества, которая позволит эффективно регулировать отношения субъектов деятельности в сфере защиты объектов, уязвимых в террористическом отношении (далее - ОУТО).

Авторами статьи проведен анализ нормативной правовой базы. Выявлены условия, препятствующие развитию отрасли. Изучено послание Президента Казахстана в части направлений развития системы государственного управления. Проведено моделирование процессов и связей между субъектами деятельности в сфере защиты ОУТО.

Выявлена главная причина недостаточного уровня защиты, которая сводится к отсутствию критериев оценки систем защиты по качественным показателям. Определено, чему способствует недостаточная компетенция технических специалистов, разрабатывающих требования к системам и игнорирование применения стандартов, а также недостаточным вовлечением профессионального сообщества в контроль над деятельностью субъектов рынка. Авторами статьи предложена модель системы управления деятельностью по защите ОУТО, которая позволит повысить качество процессов и обеспечит результат за счет дополнительного вовлечения профессионального сообщества и разработки нормативно-правовых документов. Кроме того, модель соответствует курсу развития системы государственного управления, который установлен руководством страны. Сформулирован ряд предложений по реализации новой модели системы управления защитой ОУТО. Модель описывает взаимодействие государственных органов и профессионального сообщества.

Ключевые слова: безопасность, видеонаблюдение, система, охрана, защита, сигнализация.

Date of receipt of the manuscript to the editor: 2021/04/13. 